\title{
The Relation Between Personality Traits and Violence Tendency in Nursing Students
}

\section{Hemşirelik Öğrencilerinin Kişilik Özellikleri ile Şiddet Eğilimi Arasındaki İlişki}

\author{
Afitap Özdelikara ${ }^{1}$ (D) Ahsen Taştan ${ }^{1}$ (D) Burak Arslan ${ }^{1}$ \\ ${ }^{1}$ Ondokuz Mayis University Faculty of Health Sciences, Department of Nursing/Department of Internal Medicine Nursing, Samsun,
} TURKEY

Gelis tarihi/ Date of receipt: 30/10/2020 Kabul tarihi/ Date of acceptance: 16/07/2021

(C) Ordu University Faculty of Health Sciences, Department of Nursing, Turkey, Published online: 26/12/2021

\begin{abstract}
Objective: Nurses usually become either the victims or witnesses of violence in the hospital environment up from pupilage. It is observed that the tendency to violence, besides interpersonal clashes, plays an important role in acts of violence. This study aimed to define the personality traits of nurses and the relation between such traits and the tendency to violence.

Methods: This is a descriptive study, and its population comprises of the state/foundation university of nursing students. It was aimed to reach all the students without sampling, and the research was completed with 272 nursing students (participation rate $70.4 \%$ ) who agreed to participate in the study. The data were collected through 9 question Personal Questionnaire Form, the Five Factor Personality Traits Scale (FFPTS) and Violence Tendency Scale (VTS). The analysis of the data was done with the IBM SPSS 20 package program using percentage calculations, minimum and maximum values, One Way ANOVA and Pearson correlation analysis.

Results: While from among the Five Factor Personality Traits Scale (FFPTS) sub-dimension score averages the "self-discipline" personality trait of participating students was the highest with $3.52 \pm 0.47$, this was followed by "openness to improvement" with $3.43 \pm 0.44$, "compliance" with $3.42 \pm 0.40$ and "extraversion" with $3.39 \pm 0.46$. "Neuroticism" personality trait had the lowest score average with $3.27 \pm 0.41$. The "Violence Tendency Scale (VTS)" score average of students was found as $40.26 \pm 10.46$. The relationship between the FFPTS sub-dimensions and the mean VTS score is not statistically significant.

Conclusion: No statistically significant relation was found between the Five Factor Personality Traits Scale sub-dimensions and violence tendency. It was determined that students most frequently displayed "self-discipline" and "openness to improvement" personality traits and their tendency to violence was "low" level.

Keywords: Student, nursing, health, violence, tendency, personality
\end{abstract}

\section{ÖZ}

Amaç: Hemşireler, öğrencilik döneminden başlayarak sağlık bakım ortamlarında çoğu zaman şiddetin ya kurbanı ya da tanığı olmakta ve bunun sonucunda şiddet gösterme isteği yaşayabilmektedir. Şiddet olaylarının arkasında, kişiler arası çatışmanın yanı sıra şiddet eğiliminin önemli bir etmen olduğu vurgulanmaktadır. Bu çalışma ile hemşirelik öğrencilerinin kişilik özelliklerinin belirlenmesi ve bu özelliklerin şiddet eğilimleri ile ilişkisinin saptanması amaçlanmıştır.

Yöntem: Tanımlayıcı tipte olan araștırmanın evrenini 2018-2019 eğitim öğretim yılı güz döneminde bir devlet/vakıf üniversitesinin hemșirelik bölümünde öğrenim gören 386 öğrenciden 272 öğrenci oluşturmuştur. Araştırmada örneklem seçimine gidilmemiş, evrenin tümü örnekleme alınmış olup araştırma çalıșmaya katılmayı kabul eden 272 hemşirelik öğrencisi (katılım oranı \%70,4) ile tamamlanmıștır. Araștırma verilerinin toplanmasında 9 soruluk tanıtıı bilgi formu, Beş Faktör Kişilik Özellikleri Ölçeği (BFKÖ) ve Şiddet Eğilimi Ölçeği (ŞEÖ) kullanılmıştır. Verilerin analizi IBM SPSS 20 paket programında frekans, ortalama, yüzdelik hesaplamaları, minimum ve maksimum değerleri, Independent Samples t testi, One Way ANOVA ve Pearson korelasyon analizi kullanılarak yapılmıștır.

Bulgular: Araştırmaya katılan öğrencilerin Beş Faktör Kişilik Özellikleri Ölçeği (BFKÖ) alt boyut puan ortalamalarından "özdisiplin" kişilik özelliği $3.52 \pm 0.47$ ile en yüksek puan ortalamasına sahipken, bunu 3.43 \pm 0.44 ile "gelişime açıklık", $3.42 \pm 0.40$ ile "uyumluluk" ve $3.39 \pm 0.46$ ile "dıșadönüklük" alt boyutu takip etmektedir. En düşük puan ortalaması ise, $3.27 \pm 0.41$ ile "nevrotiklik" kişilik özelliği olmuştur. Öğrencilerin "Şiddet Eğilimi Ölçeği (ŞEÖ)” puan ortalaması ise $40.26 \pm 10.46$ olarak bulunmuştur. BFKÖ alt boyutları ile ŞEÖ puan ortalaması arasında ilişki istatistiksel olarak anlamlı değildir.

Sonuç: Beş Faktör Kişilik Özellikleri Ölçeği alt boyutları ile şiddet eğilimi arasında istatistiksel olarak anlamlı ilişki saptanmamıştır. Öğrencilerin çoğunlukla özdisiplin ve gelişime açık kişilik özelliklerini sergiledikleri ve şiddet eğilimlerinin 'az' düzeyde olduğu belirlenmiştir.

Anahtar Kelimeler: Öğrenci, hemşirelik, sağlık, şiddet, eğilimler, kişilik

ORCID IDs of the authors: AÖ: 0000-0002-5896-9207; AT: 0000-0002-0263-8855; BA: 0000-0002-4981-2806

Sorumlu yazar/Corresponding author: Res. Assist. Ahsen Taştan

Ondokuz Mayıs University Faculty of Health Sciences, Department of Nursing, Samsun, TURKEY

e-posta/e-mail: ahsen.tastan@omu.edu.tr

*Presented as a poster paper by the authors of the study at the International Congress of Black Sea Nursing Education Congress with the title " The Relation Between Personality Traits and Violence Tendency in Nursing Students".

Attf/Citation: Özdelikara A, Taştan A, Arslan B. (2021). The relation between personality traits and violence tendency in nursing students. Ordu Üniversitesi Hemşirelik Çalışmaları Dergisi. 4(3), 357-367. DOI: 10.38108/ouhcd.818203 


\section{Introduction}

Personality is defined as "the combination of characteristics or qualities that form an individual's distinctive character" (Oxford Dictionary, 2018). It's a concept consistent with the inner and exterior environment of an individual distinguishing them from others which comprises special behaviors and is affected by the individual's social environment (Ulu, 2016). Allport defines personality as the dynamic organization within the individual of those psychophysical systems that determine his characteristic behavior and thought." (Allport,1961). The dynamic organization mentioned here means the adaptation of the individual to environmental and inner stimuli and them being in a state of constant change (Ulu, 2016).

Violence is defined as "Behaviour involving physical force intended to hurt, damage, or kill someone or something." (Oxford Dictionary, 2018). According to the report of the World Health Organization (WHO), violence has been defined as "the intentional use of physical force or power, threatened or actual, against oneself, another person, or against a group or community that either results in or has a high likelihood of resulting in injury, death, psychological harm, maldevelopment or deprivation." Each year, 1.3 million individuals lose their lives as a result of violence, and violence ranks 4th among the causes of death for the age group 1544 (WHO, 2014).

It is known that there exists a relation between personality traits and submissive and prone to violence behaviors of individuals (Arslantaş et al., 2012). It was reported that the personality of individuals exposed to violence from their mother or father or bore witness to violence within the family during the personality formation and settling period including babyhood and childhood developed with identification, and such persons became prone to violence (Yüksel et al., 2015). During the personality formation period, other people, with whom the individuals interact with, have a determining role on violence tendency (Özsoy and Y1ld1z, 2013).

In their study, Kaya et al. (2004), stated that personality traits and bearing witness to violence played a role in developing submissive behaviors and displaying obedient behavior patterns (Kaya et al., 2004). American social psychologist Stanley Milgram showed in their Milgram Experiment conducted in the 1960s that individuals who had submissive behaviors and exhibited obedient behaviors had a higher tendency to commit violence and violence potential (Kaya et al., 2004). Taking into consideration all these studies, one may question whether the tendency to violence was connected with personal traits.

Violence in the health field comes frequently to the fore. Previous studies showed that violence was committed most frequently in the health field compared to other work places and health personnel was under the risk of being subjected to violence 16 times more than workers of other fields (Özcan and Bilgin, 2011).

Analyzing occupational groups, it was reported that nurses were being subjected to violence more frequently compared to other occupational groups (Ayranc1 et al., 2006). In their study, Gökçe and Dündar reported that $90 \%$ of the nurses were subjected to violence (Gökçe and Dündar, 2010). Hence, nurses are obliged to develop behaviors for ever-changing environments and conditions (Yüksel et al., 2015). Nurses can be within the group who commit or are subject to violence within the health system. To determine and control the violence tendency of nurses who provide care to people becomes vital in terms of protecting, developing and rehabilitating public health (Yüksel et al., 2015). Insubmissive, self-confident and assertive nurses could also fulfill the leadership role and that to assert patient rights (Arslantaş et al., 2012). It is important that nurses have proper behavior patterns up from the education phase. Besides theoretical courses, nursing students also attend the hospital environment in practice and faced with a variety of situations in interpersonal relationships. (Arslantaş et al., 2012). In their study, Haskan and Yildırım (2012) observed that behind acts of violence, violence tendency plays an important role besides interpersonal conflicts. Thus, this study aimed to determine the personality traits of nursing students and the relationship between these traits and violence tendency.

\section{Research questions}

- What are the personality traits of nursing students?

- What is the level of violence tendencies of nursing students?

- Do personality traits have any effect on violence tendency in nursing students?

\section{Material and Method}

The descriptive research was conducted face-toface and its universe consists of 386 active nursing students enrolled in a state / foundation university in the 2018-2019 academic year. We aimed to reach all 
the students without sampling, and 272 voluntary students partook in the study (Participation rate: $70,4 \%$ ). The data were collected through 9 question Personal Information Form, the Five Factor Personality Traits Scale (FFPTS) and Violence Tendency Scale (VTS) prepared in the light of the literature.

\section{Data Collecting Instrument}

\section{The Personal Questionnaire Form}

The personal information form consists of 9 questions such as age, gender, marital status, perception of academic achievement, evaluation of mother and father attitude, exposure to violence, and reaction to violence (Y1ld1z and Erci, 2011; Karabulutlu, 2015).

Five Factor Personality Traits Scale (FFPTS)

The five-point Likert-type scale developed by Benet-Martinez and John (1998) consists of 44 items. The Turkish adaptation of the study conducted in 56 countries by Schmitt et al., (2007) has been done by Sümer (2005). The scale consists of five sub-dimension; "Neuroticism", "Extraversion", "Openness to Improvement", "Compliance" and "Self-discipline" in order to evaluate personality traits. High scores from each sub-dimension show that the individual has that personality trait at a high level. In the study by Schmitt et al. (2007), the Cronbach's alpha values of the five factor personality scale was defined as .79 for "neuroticism", .77 for "extraversion", .76 for "openness to improvement", .70 for "compliance" and .78 for "self-discipline" dimensions. On the other hand, the Cronbach's alpha values were defined to vary between .64 and .77 according to the study by Sümer (2005). In this study, the Cronbach's alpha values of the five factor personality scale was defined as .72 for the extraversion sub-dimension, .70 for the compliance sub-dimension, .64 for the self-discipline sub-dimension, .72 for the neuroticism sub-dimension, and .74 for the openness to improvement sub-dimension.

\section{Violence Tendency Scale (VTS)}

The scale was developed by Göka et al. in 1995 to be used in the research titled "Aggressiveness and Violence Tendencies of Secondary School Students" conducted by the Ministry of National Education (Republic of Turkey Prime Ministry Institution of Family Research 1998). Thereafter, the fundamental structure of the scale was refigured and, validating the content, used in the research titled "Domestic and Social Violence" of the
Republic of Turkey Prime Ministry Institution of Family Research. The scale is quadruple Likert type and consists of 20 items. Assessment is done giving 4 points to the "Very Appropriate" option and 1 point to the "Not Appropriate at All" option. In assessments done according to the total scores, a score between 1-20 shows that the aggressiveness tendency of the student is "very low", while a score between 21-40 shows that it's "low", a score between 41-60 it's "high" and a score between 6180 that it's "very high".

\section{Statistical Analyses}

Data analysis was done through the IBM SPSS 20 (Statistical package for the social sciences- Demo Version 20 Chicago, IL, USA) package program. The homogeneity of the data was tested with Kolmogorov Smirnov. The analysis of the data was done by using frequency, mean, percentage calculations, minimum and maximum values, Independent Samples t test, One Way ANOVA and Pearson correlation analysis.

\section{Results}

Of the participating students, $80.5 \%$ informed that they were female, 73.5 between the ages of 18 21 and $96.3 \%$ single. $57.4 \%$ defined the academic standing perception as "mediocre" and $35.3 \%$ as "good". 75.7\% reported that their mothers had a democratic attitude, while $73.5 \%$ reported the same for their fathers. $85.7 \%$ of the students reported they were not subjected to physical violence, while $57.7 \%$ reported the same for verbal violence. $48.2 \%$ stated their reaction against violence as "I would equally retaliate", while $21 \%$ stated it to be as "I would remain unresponsive" (Table 1).

Analyzing the VTS score averages according to sociodemographic variants in Table 1; it was determined that the score average of male students was $46.30 \pm 12.09$ and this value was higher than that of female students. The score average of students who reported their mothers' attitude as oppressive was found higher than that of other groups with $43.43 \pm 9.71$. The students who gave the answer "I would retaliate physically regardless the type of violence" against violence formed the group with the highest score average with $45.62 \pm 10.35$. It was found that there was a statistically significant relationship between the gender variant ( $\mathrm{p}: 0.000)$,mothers' attitude $(\mathrm{p}<0.05)$, the difference between the action against violence (p:0.003) and VTS score average (Table 1). 
Table 1. The Identifier Traits and VTS Score Average of Students $(n=272)$

\begin{tabular}{|c|c|c|c|}
\hline $\begin{array}{l}\text { Sociodemographic } \\
\text { Data }\end{array}$ & n & $\%$ & VTS Score Average, test and $p$ \\
\hline \multicolumn{4}{|l|}{ Gender } \\
\hline Female & 219 & 80.5 & $38.89 \pm 9.57$ \\
\hline Male & 53 & 19.5 & $\begin{array}{c}46.30 \pm 12.09 \\
\mathrm{t}: 4.501 \mathbf{p : ~ 0 . 0 0 0}\end{array}$ \\
\hline \multicolumn{4}{|l|}{ Age } \\
\hline $18-21$ & 200 & 73.5 & $39.86 \pm 9.43$ \\
\hline $22-25$ & 67 & 24.6 & $41.71 \pm 12.91$ \\
\hline $26-29$ & 3 & 1.1 & $36.66 \pm 12.50$ \\
\hline \multirow[t]{2}{*}{30 and above } & 2 & 0.7 & $30.00 \pm 00.00$ \\
\hline & & & F: 0.937 p: 0.423 \\
\hline \multicolumn{4}{|l|}{ Marital Status } \\
\hline Married & 10 & 3.7 & $36.11 \pm 7.45$ \\
\hline Single & 262 & 96.3 & $\begin{array}{c}40.42 \pm 10.53 \\
\mathrm{t}: 1.214 \text { p: } 0.226\end{array}$ \\
\hline \multicolumn{4}{|l|}{ Perception of Academic Success } \\
\hline Good & 96 & 35.3 & $38.82 \pm 0.96$ \\
\hline Mediocre & 156 & 57.4 & $40.54 \pm 11.25$ \\
\hline $\mathrm{Bad}$ & 20 & 7.4 & $45.29 \pm 8.85$ \\
\hline & & & $\mathrm{F}: 2.888 \mathrm{p}: 0.058$ \\
\hline \multicolumn{4}{|l|}{ Mother's Attitude Assessment } \\
\hline Democratic $^{a}$ & 206 & 75.7 & $39.53 \pm 10.63$ \\
\hline Oppressive $^{\mathrm{b}}$ & 57 & 21.0 & $43.43 \pm 9.71$ \\
\hline \multirow{2}{*}{ Undisciplined-Inconsistent ${ }^{\mathrm{a}}$} & 9 & 3.3 & $36.50 \pm 7.23$ \\
\hline & & & F: 3.479 p: $\mathbf{0 . 0 3 2}$ \\
\hline \multicolumn{4}{|l|}{ Father's Attitude Assessment } \\
\hline Democratic & 200 & 73.5 & $40.01 \pm 10.22$ \\
\hline Oppressive & 55 & 20.2 & $42.04 \pm 11.36$ \\
\hline \multirow[t]{2}{*}{ Undisciplined-Inconsistent } & 17 & 6.3 & $37.81 \pm 10.25$ \\
\hline & & & F: 1.186 p: 0.307 \\
\hline \multicolumn{4}{|l|}{ Subjected to Verbal Violence } \\
\hline Yes & 115 & 42.3 & $40.71 \pm 11.33$ \\
\hline \multirow{2}{*}{ 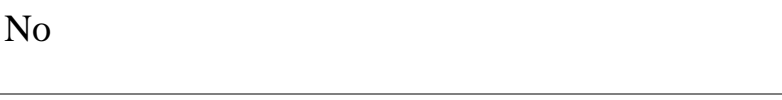 } & 157 & 57.7 & $39.93 \pm 9.79$ \\
\hline & & & t: 0.586 p: 0.567 \\
\hline \multicolumn{4}{|l|}{ Subjected to Physical Violence } \\
\hline Yes & 39 & 14.3 & $39.27 \pm 12.25$ \\
\hline \multirow[t]{2}{*}{ No } & 233 & 85.7 & $40.41 \pm 10.18$ \\
\hline & & & $\mathrm{t}: 0.584 \mathrm{p}: 0.613$ \\
\hline \multicolumn{4}{|l|}{ Reaction Against Violence } \\
\hline -I would equally retaliate. ${ }^{\mathrm{a}}$ & 131 & 48.2 & $42.27 \pm 9.83$ \\
\hline -I would remain unresponsive. ${ }^{\mathrm{b}}$ & 57 & 21.0 & $37.60 \pm 10.51$ \\
\hline \multirow{5}{*}{$\begin{array}{l}\text {-I would retaliate against physical violence but } \\
\text { remain unresponsive against verbal violence. }^{\text {ab }} \\
\text {-I would retaliate physically regardless the type of } \\
\text { violence. }{ }^{\text {ab }} \\
\text {-Other }{ }^{\text {ab }}\end{array}$} & & & \\
\hline & 32 & 11.8 & $41.06 \pm 11.78$ \\
\hline & 9 & 3.3 & $45.62 \pm 10.35$ \\
\hline & 43 & 15.8 & $36.36 \pm 9.52$ \\
\hline & & & F: 4.119 p: $\mathbf{0 . 0 0 3}$ \\
\hline
\end{tabular}


No statistically significant relationship was found between the age, marital status, perception of academic success and father's attitude assessment, subjected to verbal and physical violence and VTS score average ( $p>0.05)$ (Table 1$)$.

While from among the Five Factor Personality Traits Scale (FFPTS) sub-dimension score averages the "self-discipline" personality trait of participating students was the highest with $3.52 \pm 0.47$, this was followed by "openness to improvement" with $3.43 \pm 0.44$, "compliance" with $3.42 \pm 0.40$ and "extraversion" with $3.39 \pm 0.46$. "Neuroticism" personality trait had the lowest score average with $3.27 \pm 0.41$. The "Violence Tendency Scale (VTS)" score average of students was found as $40.26 \pm 10.46$ and and low level, (Table 2).

Table 2. The Five Factor Personality Traits and Violence Tendency Score Averages of Students $(n=272)$

\begin{tabular}{llllc}
\hline & Sub-dimensions & Avg. \pm SS & Min. & Max. \\
\cline { 2 - 4 } & Neuroticism & $3.27 \pm 0.41$ & 2.00 & 5.00 \\
\cline { 2 - 4 } & Extraversion & $3.39 \pm 0.46$ & 1.00 & 5.00 \\
\cline { 2 - 4 } & Openness to Improvement & $3.43 \pm 0.44$ & 2.00 & 5.00 \\
\cline { 2 - 4 } & Compliance & $3.42 \pm 0.40$ & 2.22 & 5.00 \\
\cline { 2 - 4 } & Self-discipline & $3.52 \pm 0.47$ & 1.78 & 5.00 \\
\hline VTS & & $40.26 \pm 0.46$ & 20.00 & 80.00 \\
\hline
\end{tabular}

Considering the sociodemographic data and the FFPTS sub-dimension score averages distribution, the score averages of all the FFPTS sub-dimensions for students in the age group of 18-21 was found high, and the relationship between the age variant and "neuroticism", "extraversion" and "self-discipline" FFPTS sub-dimensions was found to be significant $(\mathrm{p}<0.05)$ (Table 3).

All FFPTS sub-dimension score averages were found higher in singles. The difference between "neuroticism" and "compliance" subdimensions and marital status was found to be statistically significant $(\mathrm{p}<0.05)$. It was determined that students who perceived their academic standing as good had higher FFPTS sub-dimensions score averages than other groups, and that the difference between academic success perception and "extraversion", "openness to improvement" and "compliance" sub-dimensions was statistically significant $(\mathrm{p}<0.05)$. No statistically significant relationship was found between gender, mother's attitude assessment, father's attitude assessment and VTS score average $(\mathrm{p}>0.05)$ (Table 3).

Table 4 shows the relationship between the students' FFPTS and VTS score averages. According to this; while a weak positive relationship was determined between the "extraversion" sub-dimension and the VTS score average; a weak negative relationship was determined between the "openness to improvement", "compliance" and "selfdiscipline" sub-dimensions and the VTS score average. No statistically significant relationship was found between the FFPTS sub-dimensions and the VTS score average. $(r<0.25)(p>0.05)$ (Table 4). 
Table 3. The Sociodemographic data and FFPTS sub-dimension score averages of students

\begin{tabular}{|c|c|c|c|c|c|}
\hline \multirow{2}{*}{$\begin{array}{l}\text { Sociodemographic } \\
\text { Data }\end{array}$} & \multicolumn{5}{|c|}{ Five Factor Personality Traits (FFPTS) } \\
\hline & Neuroticism & Extraversion & $\begin{array}{l}\text { Openness to } \\
\text { improvement }\end{array}$ & Compliance & Self-discipline \\
\hline \multicolumn{6}{|l|}{ Gender } \\
\hline Female & $3.27 \pm 0.42$ & $3.40 \pm 0.46$ & $3.43 \pm 0.45$ & $3.43 \pm 0.41$ & $3.53 \pm 0.47$ \\
\hline \multirow[t]{3}{*}{ Male } & $3.29 \pm 0.35$ & $3.35 \pm 0.43$ & $3.46 \pm 0.38$ & $3.40 \pm 0.36$ & $3.43 \pm 0.45$ \\
\hline & $\mathrm{T}: 0.192$ & $\mathrm{t}: 0.598$ & $\mathrm{t}: 0.380$ & $\mathrm{t}: 0.381$ & $\mathrm{t}: 1.089$ \\
\hline & p: 0.848 & $\mathrm{p}: 0.551$ & p: 0.705 & p: 0.704 & p: 0.278 \\
\hline \multicolumn{6}{|l|}{ Age } \\
\hline 18-21 & $3.32 \pm 0.40^{\mathrm{a}}$ & $3.42 \pm 0.43^{\mathrm{a}}$ & $3.44 \pm 0.41$ & $3.44 \pm 0.40$ & $3.56 \pm 0.46^{\mathrm{a}}$ \\
\hline $22-25$ & $3.18 \pm 0.40^{\mathrm{ab}}$ & $3.36 \pm 0.43^{\mathrm{a}}$ & $3.42 \pm 0.51$ & $3.37 \pm 0.41$ & $3.36 \pm 0.45^{b}$ \\
\hline 26-29 & $3.25 \pm 0.17 \mathrm{ab}$ & $3.06 \pm 0.08^{a b}$ & $3.27 \pm 0.23$ & $3.16 \pm 0.23$ & $3.27 \pm 0.39 \mathrm{ab}$ \\
\hline \multirow[t]{4}{*}{30 and above } & $2.50 \pm 0.70^{b}$ & $2.06 \pm 1.50^{b}$ & $3.16 \pm 0.23$ & $3.11 \pm 0.15$ & $4.16 \pm 1.17^{a b}$ \\
\hline & F: 3.897 & F: 6.694 & $F: 0.363$ & $\mathrm{~F}: 1.117$ & F: 3.899 \\
\hline & df: 3 & df: 3 & df: 3 & df: 3 & df: 3 \\
\hline & p: 0.010 & p: 0.000 & $\mathrm{p}: 0.780$ & $\mathrm{p}: 0.343$ & p: 0.010 \\
\hline \multicolumn{6}{|l|}{ Marital Status } \\
\hline Married & $2.78 \pm 0.37$ & $2.78 \pm 0.84$ & $3.17 \pm 0.29$ & $3.11 \pm 0.24$ & $3.30 \pm 0.82$ \\
\hline \multirow[t]{3}{*}{ Single } & $3.29 \pm 0.40$ & $3.41 \pm 0.43$ & $3.44 \pm 0.44$ & $3.43 \pm 0.40$ & $3.52 \pm 0.45$ \\
\hline & $\mathrm{t}: 3.283$ & $\mathrm{t}: 3.649$ & $\mathrm{t}: 1.611$ & $\mathrm{t}: 2.108$ & $\mathrm{t}: 1.241$ \\
\hline & p: 0.001 & p: 0.097 & p: 0.109 & p: 0.036 & p: 0.216 \\
\hline \multicolumn{6}{|c|}{ Academic Standing Perception } \\
\hline Good & $3.31 \pm 0.44$ & $3.52 \pm 0.43^{\mathrm{a}}$ & $3.57 \pm 0.45^{\mathrm{a}}$ & $3.51 \pm 0.39^{\mathrm{a}}$ & $3.59 \pm 0.42$ \\
\hline Mediocre & $3.28 \pm 0.37$ & $3.37 \pm 0.39^{\mathrm{a}}$ & $3.38 \pm 0.41^{b}$ & $3.40 \pm 0.38^{a b}$ & $3.47 \pm 0.47$ \\
\hline \multirow[t]{4}{*}{ Bad } & $3.09 \pm 0.48$ & $3.06 \pm 0.76^{b}$ & $3.22 \pm 0.38^{b}$ & $3.21 \pm 0.49^{b}$ & $3.48 \pm 0.63$ \\
\hline & F: 2.046 & F: 7.938 & $F: 6.565$ & F: 4.401 & $\mathrm{~F}: 1.350$ \\
\hline & df: 2 & df: 2 & df: 2 & df: 2 & df: 2 \\
\hline & p: 0.132 & p: 0.000 & p: 0.002 & p: 0.013 & p: 0.262 \\
\hline \multicolumn{6}{|c|}{ Mother's Attitude Assessment } \\
\hline Democratic & $3.27 \pm 0.42$ & $3.38 \pm 0.47$ & $3.42 \pm 0.45$ & $3.41 \pm 0.40$ & $3.52 \pm 0.48$ \\
\hline Oppressive & $3.33 \pm 0.38$ & $3.50 \pm 0.38$ & $3.53 \pm 0.37$ & $3.48 \pm 0.41$ & $3.54 \pm 0.42$ \\
\hline Undisciplined- & $3.12 \pm 0.26$ & $3.17 \pm 0.57$ & $3.20 \pm 0.46$ & $3.36 \pm 0.46$ & $3.36 \pm 0.48$ \\
\hline Inconsistent & F: 0.922 & F: 2.111 & $F: 2.145$ & $F: 0.531$ & $F: 0.486$ \\
\hline & df: 2 & df: 2 & df: 2 & df: 2 & df: 2 \\
\hline & p: 0.399 & $\mathrm{p}: 0.124$ & p: 0.120 & $\mathrm{p}: 0.589$ & p: 0.616 \\
\hline \multicolumn{6}{|c|}{ Father's Attitude Assessment } \\
\hline Democratic & $3.28 \pm 0.43$ & $3.37 \pm 0.49$ & $3.45 \pm 0.44$ & $3.43 \pm 0.41$ & $3.55 \pm 0.49$ \\
\hline Oppressive & $3.23 \pm 0.35$ & $3.44 \pm 0.30$ & $3.39 \pm 0.41$ & $3.35 \pm 0.32$ & $3.42 \pm 0.41$ \\
\hline Undisciplined- & $3.31 \pm 0.38$ & $3.44 \pm 0.52$ & $3.34 \pm 0.49$ & $3.50 \pm 0.51$ & $3.42 \pm 0.32$ \\
\hline \multirow[t]{3}{*}{ Inconsistent } & F: 0.353 & F: 0.416 & F: 0.695 & F: 0.925 & F: 1.479 \\
\hline & df: 2 & df: 2 & df: 2 & df: 2 & df: 2 \\
\hline & p: 0.703 & p: 0.660 & $\mathrm{p}: 0.500$ & p: 0.398 & p: 0.230 \\
\hline
\end{tabular}

*t: Independent Samples T testi, F: One Way ANOVA, There is no difference between groups with the same letter.

Table 4. The Relationship between FFPTS and VTS Score Averages of students
FFPTS sub-dimensions
Violence Tendency
p Values

\begin{tabular}{lcc} 
Neuroticism & 0.101 & 0.168 \\
Extraversion & 0.015 & 0.841 \\
\hline Openness to Improvement & -0.013 & 0.865 \\
\hline Compliance & -0.023 & 0.750 \\
\hline Self-discipline & -0.01 & 0.984
\end{tabular}




\section{Discussion}

Analyzing the students' FFPTS sub-dimension score averages, the "self-discipline" sub-dimension was found to have the highest score average. Köse et al. (2012) found in their studies conducted with nursing students that "openness to improvement" was the sub-dimension with the highest score average (Köse et al., 2012). Öztürk et al. (2014) analyzed the personality traits of university students including the faculty of nursing and found that "compliance" sub-dimension had the highest score average (Öztürk et al., 2014). The study by Ziapour and Kianipour conducted with nurses showed that the "openness to improvement" sub-dimension of nurses was the highest (Ziapour and Kianipour, 2015). On the other hand, the study by Lourinho et al. conducted with faculty of medicine students showed also that the "openness to improvement" sub-dimension was the highest (Lourinho et al., 2016). In studies conducted in the literature with different student groups it is evident that the "openness to improvement" sub-dimension attained the highest score average. However, in our study, "openness to improvement" became the second subdimension following "self-discipline". The "selfdiscipline" (responsibility) sub-dimension consists of traits such as being disciplined, having a sense of mission, being responsible, tidiness, being meticulous and careful (Bacanlı et al., 2009). Traits associated with "self-discipline" are established in all the courses related to nursing, and students are expected to behave accordingly. It was taken into consideration that this situation might have influenced the result of the study.

It was determined that the VTS score average revealed "low" violence tendency according to the scale assessment. Similar results were attained by studies conducted with nursing students (Özpulat, 2017; Yüksel et al., 2015). In their research with nursing students, Tosunöz et al. determined the violence tendency levels of students as low (Tosunöz et al. 2019). The results of our study are in parallel with the literature (Tosunöz et al., 2019; Özpulat, 2017; Yüksel et al., 2015). The nursing profession is based on human care, and the one of the most important ethic codes is not to harm-to be beneficial. Hence, throughout the educational life of nursing students, the knowledge and skills aimed at being beneficial is established and it is supported that they develop attitudes in this direction.

Our study found that male students had a "higher" violence tendency and gender affected violence tendency. This result is in parallel with other studies (Ameri et al. 2017; Karayağız Muslu et al.,2020; Ulu, 2016; Yüksel et al. 2015). There are studies which indicate that physical aggression is environment-related for females and geneticsrelated for males (McDermott and Hatemi, 2017). It was considered that males have a higher violence tendency in relation to possessing biologically androgen and testosterone traits and due to social roles assigned to genders (Kaplan and Aksel, 2013). It could be said that sentimentality assigned to females and authority and strength-based roles assigned to males increased violence tendency in men.

Despite no significant relationship was found between age and marital status and violence tendency, it was determined that students aged 30 years and above had a lower violence tendency compared to other age groups. Another study reported that the positive attitude towards violence decreased significantly with the increase of age (Ameri et al., 2017). It is known that aggression and violence increased in individuals during the puberty period. Thus, it is an expected outcome for adult individuals outside of the puberty period to have a low violence tendency. The violence tendencies of single students were found higher than that of married ones, but no statistical significane was found. Similar to our study, Çetin and Erdoğan also reported in their study conducted with male individuals that marital status had no effect on violence tendency (Çetin and Erdoğan, 2017). There are studies in the literature indicating that marital status had no effect on violence tendency (Ameri et al., 2017).

It was determined that as the perception of academic success of students decreased, the violence tendency increased. In studies conducted with high school students, a negative relationship was found between school attachment and violence tendency (Bellici et al., 2015). A low academic success and weak school attachment increase violent and aggressive behaviors (Avc1 and Yildırım, 2015). It was considered that failure could create insufficiency, loss of social acknowledgement and anger for the adolescent university student, and thus increase violence tendency.

It is striking that the VST score averages of students whose mother displayed an oppressive attitude were high. The difference between the mother's attitude and violence tendency was found to be significant. It is reported in the literature that uncaring, undisciplined and etc., inadequate attitudes of families supported the tendency to 
violence (Y1ldiz and Erci, 2011). The study by Karayağız Muslu et al. (2020) determined the effect of family type on violence tendency and found that the violence tendency of students with broken families was high (Karayağı Muslu et al., 2020). Taking into consideration that parents who try to control the child oppressively base their behaviors on physical or verbal violence; it is a fact that parents try to ensure that the child acts as they wish through oppression and violence. In oppressing families, rules are strictly applied for the child. Hence, a high violence tendency is expected of children who grow up facing such an attitude.

No significance was found between having been subject to verbal or physical violence before and violence tendency, nevertheless, the violence tendencies of students giving the answers "I would retaliate physically regardless the type of violence" and "I would retaliate against physical violence, but remain unresponsive against verbal violence" was found to be high. In their study, Kanbay et al. (2012) reported that $44.1 \%$ of nursing students became the subject of violence and $57.6 \%$ committed violence to another individual in a period in their lives (Kanbay et al., 2012). Another study with nursing students reported that $28.2 \%$ of students committed violence to another individual (Karabulutlu, 2015). One other study found the violence tendencies of students who became the subject of violence themselves high, and a positively significant relationship was reported between being subject to violence and violence tendency (Karayağız Muslu et al., 2020). Being witness or subject to domestic violence during childhood constitutes a risk factor for crimes of violence. Being witness or subject to domestic violence and stereotypical gender roles in society can form a basis for crimes of violence (Ulu, 2016). It is possible that individuals who witness violent behaviors within the family or become subjected to or witness violence later on consider using violence as feasible. In our study, it is considered that $48.2 \%$ of students stated that they would equally retaliate due to this.

According to the sociodemographic data of students, analyzing the FFPTS score averages; it was determined that male students displayed "neuroticism" and "openness to improvement" personality traits more; while female students displayed "extraversion", "compliance" and "selfdiscipline" personality traits more. In the study by Tatlılığlu (2014) with university students, it was reported that the personality traits sub-dimension score averages of female students were high and, similar to our study, no statistically significant relationship was found between gender variant and personality traits (Tatlılıoğlu, 2014). It was found that as the age average of students decreased all subdimensions except for "self-discipline" increased and, on the other hand, students aged 30 years and above got a higher score from the "self-discipline" sub-dimension. Statistically significant difference was found between the age variant and "neuroticism", "extraversion" and "self-discipline". The late puberty period starts at 18 and ends with the integration of the sense of identity. The person in this period is in identity confusion, and it is difficult to establish a consistent identity without gains which are expected to be attained in the developmental stages such as basic confidence, self-determination, entrepreneurship, work and constructiveness (Derman, 2008). Hence, it is considered that the results have been affected due to the puberty period the students in the age group 18-21 are within. That the "self-discipline" sub-dimension is found high in students aged 30 years and above can be interpreted as an outcome of the skill to take responsibility of the adolescent individual due to their age group.

The FFPTS sub-dimension score averages of single students were found higher than those of married ones. The difference between marital status and "neuroticism" and "compliance" was found to be statistically significant. It is an expected outcome that single students have high "extraversion" and "compliance" sub-dimension score averages as such students are more active and spend more time within their social groups.

The "extraversion", "compliance" and "openness to improvement" personality traits score averages of students who perceived their academic success as good were found to be high. While "extraversion" refers to one's ability to express him/herself, ease and "openness" in relations with others; "compliance" consists of traits such as friendliness, enjoying group work, putting effort and tolerance. Extravert persons are open to innovations and changes, creative, intellectual, open-minded and curious. Thus, such traits support academic success (Komarraju et al., 2009).

No significant relationship was found between personality traits according to the attitude of the mother and father. Nevertheless, the FFPTS subdimension score averages of students with an oppressive mother were found high. In Tatlllığlu's study (2014), a statistically significant relationship was found between the mother-father's attitude and "extraversion", "neuroticism" and "openness to 
improvement". Y1ld1z and Erci (2011) also reported in their studies that the attitude of an authoritative mother-father increased the aggressiveness level (Y1ldiz and Erci, 2011). Considering the results of this study, it is thought that personality traits are not solely dependent on the parent attitude.

Analyzing the FFPTS and VTS correlation results; it was found that as the "neuroticism" and "extraversion" personality traits increased, so did violence tendency; whereas as "compliance", "openness to improvement" and "self-discipline" personality traits increased violence tendency decreased. It was not statistically significant. In their study, Ulloa et al. (2016) reported that the "neuroticism", "extraversion" and "openness to improvement" personality traits constituted risk factors for partner violence (Ulloa et al., 2016). Similar results can be found in the literature (Ulu, 2016; Yöyen, 2017). Supporting the results of our study, Yöyen's study (2017) found a significant and positive relationship between violence types and the "neuroticism" personality trait. The same study reported that individuals displaying the "extraversion" personality trait adapted verbal violence from among violence types (Yöyen, 2017). Neurotic individuals are generally anxious, mistrustful, protectionist, nervous and worried, while extravert individuals enjoy change, are carefree, indifferent and untroubled, but hottempered and can lose themselves and are not always successful in controlling their emotions and restrain themselves.(Tatlılığlu, 2014). Hence, it was considered that these traits of "neuroticism" and "extraversion" affected violence tendency in the same direction. While "openness to improvement" consists of traits such as artistic thinking and being sensitive, flexible, creative, cultured and intellectual; "compliance" consists of traits such as being more constructive in interpersonal conflicts and having an attitude reducing work-family conflicts. "Self-discipline" reflects a responsible, dependent, careful, disciplined and determined personality with a strong success motive (Tatlılığlu, 2014). Considering these personality traits, it could be said that such individuals tend to isolate themselves from conflicts.

\section{Conclusion and Recommendations}

In conclusion of our study, it could be said that nursing students displayed the "self-discipline" personality trait. As a result of the strengthening of the disciplinary understanding present in the nature of the nursing profession throughout nursing education, this personality trait became firm in students. The violence tendencies of students were determined as "low". Considering that the nursing profession should be practiced on the basis of patience and devotion, this is a desirable outcome. It was found that gender, mother's attitude and type of reaction against violence had an effect on violence tendency. While it was determined that age, marital status and perceived academic success had an effect on personality traits, no significant relationship was found between personality traits and violence tendency.

In line with these results; it is considered to be important to support the openness to improvement personality trait during nursing education besides applications strengthening "self-discipline". To that end, it is recommended to use student-centered methods which make the student active and direct them to research; reducing the usage of studentpassivizing methods. All factors which will create violence tendency in students should be thoroughly evaluated, and it should be ensured to conserve already present violence tendency, which is at the desired level. However, while controlling conditions which will increase the violence tendency of students, it should also be prevented that they become subjected to violence. Therefore, it is of utmost importance to enhance students' awareness of not only physical and verbal violence but also any kind of violence. It is important that lecturers and students are aware of conditions which have an effect on violence tendency, however, these circumstances should not be introduced as justifications of violence, and wrong messages should not be given. The relationship between personality traits and violence tendency should be known. In accordance with this, personality traits which have a negative relationship with violence tendency should be strengthened, and students should be encouraged to bring to the forefront such personality traits.

\section{Limitations of the Study}

The sample size of this study is limited and it is limited in terms of generalizability to society.

\section{Acknowledgments}

We would like to thanks all participants students for their contribution.

Ethics Committee Approval: Approval was taken from the Ondokuz Mayıs University Social and Human Sciences Ethics Committee (2017/148). Participants were 
informed about the purpose of the research and was conducted in accordance with the Declaration of Helsinki. Written approval was taken from Ondokuz Mayis University Faculty of Health Sciences and verbal from participant students.

Peer-review: External referee evaluation.

Author Contributions: Concept: AÖ, AT, BA; Design: AÖ, AT; Supervision: AÖ; Data Collection: AT, BA; Data Processing: AT, AÖ; Analysis and Interpretation: AT, AÖ; Literature Search: AT; Preparation of the manuscript: AT, AÖ; Critical Reviews: AÖ, AT, BA.

Conflict of interest: The authors declare that they have no conflict of interest.

Financial Disclosure: No financial support has been received for this research.

\section{What did the study add to the literature?}

- It reveals the personality traits that students need to be supported in nursing education.

- It supports the teaching staff and students to be aware of the situations that affect the tendency to violence.

\section{References}

Allport GW. (1961). Pattern and growth in personality. New York: Holt, Rinehart and Winston, p.11.

Ameri Z, Mirzakhani F, Nabipour AR, Khanjani N, Sullman MJ. (2017). The relationship between religion and risky behaviors among Iranian university students. Journal of Religion and Health, 56(6), 20102022.

Arslantaş H, Adana F, Bağcı S, Ayva E. (2012). Hemşirelik ve ebelik öğrencilerinin klinik uygulamalarında karşılaştıkları şiddetin boyun eğici davranışlar ve bazı değişkenlerle ilişkisi. Florence Nightingale Hemşirelik Dergisi, 20(1), 53-61.

Ayrancı U, Yenilmez C, Balcı Y, Kaptanoğlu C. (2006). Identification of violence in Turkish health care settings. Journal of Interpersonal Violence, 21(2), 276-296.

Avcı ÖH, Yıldırım İ. (2015). Ergenlerde şiddet eğiliminin görülme sıklığı. Kuramsal Eğitimbilim Dergisi, 8(1), 106-124

Bacanlı H, İlhan T, Aslan S. (2009). Beş faktör kuramına dayalı bir kișilik ölçeğinin geliștirilmesi: sıfatlara dayalı kişilik testi (SDKT). Journal of Turkish Educational Sciences, 7(2), 261-279.

Bellici N, Sardoğan M, Yılmaz M. (2014). Lise öğrencilerinde okula bağlanma ve şiddet eğilimi arasındaki ilişkinin cinsiyet ve sınıf değişkenlerine göre incelenmesi. Accessed date:29.10.2020, https://www.academia.edu/10572946/Lise_\%C3\%96 $\%$ C4\%9Frencilerinde_Okula_Ba\%C4\%9Flanma_ve _\% $5 \% 9$ Eiddet_E\%C4\%9Filimi_Aras\%C4\%B1nda ki_\%C4\%B0li\%C5\%9Fkinin_Cinsiyet_ve_S\%C4\% B1n\%C4\%B1f_De\%C4\%9Fi\%C5\%9Fkenlerine_G \%C3\%B6re_\%C4\%B0ncelenmesi
Benet-Martinez V, John OP. (1998). Los cinco grades across cultures and ethnic groups: Multitraitmultimethod Analyses of the big five in Spanish and English. Journal of Personality and Social Psychology, 75, 729-750.

Çetin ÖI, Erdoğan S. (2017). Genç erişkin erkeklerde şiddet eğilimi ve psikolojik durum ile ilişkisi. Florence Nightingale Hemşirelik Dergisi, 25(2), 7784.

Derman O. (2008). Ergenlerde psikososyal gelişim. Adolesan Sağlığı II Sempozyum Dizisi, 63, 19-21.

Gökçe T, Dündar C. (2010). Samsun Ruh ve Sinir Hastalıkları Hastanesi'nde çalışan hekim ve hemşirelerde şiddete maruziyet sıklığı ve kayg1 düzeylerine etkisi. Journal of Inonu University Medical Faculty, 15(1), 25-28.

Haskan Ö, Yıldırım İ. (2012). Şiddet eğilimi ölçeği'nin geliştirilmesi. Eğitim ve Bilim, 37(163), 165-177.

Kanbay Y, Işık E, Yavuzaslan M, Keleş S. (2012). Hemşirelik öğrencilerinin kadına yönelik aile içi şiddetle ilgili görüş ve tutumlarının belirlenmesi. Gümüşhane Üniversitesi Sağlık Bilimleri Dergisi, 1(2), 107-119.

Kaplan B, Aksel EŞ. (2013). Ergenlerde bağlanma ve saldırganlık davranışları arasındaki ilişkinin incelenmesi. Nesne Psikoloji Dergisi, 1(1), 20-49.

Karabulutlu Ö. (2015). Nursing students views and experiences of violence. Journal of Hacettepe University Nursing Faculty, 26-36.

Karayağız Muslu G, Coşkun Cenk S, Sarlak D. (2020). An analysis of the relationship between high school students' tendency toward violence, self-esteem, and competitive attitude. Journal of Interpersonal Violence, 35(23-24), 5976-5996. doi: 10.1177/0886260517723742.

Kaya M, Güneş G, Kaya B, Pehlivan E. (2004). Tıp fakültesi öğrencilerinde boyun eğici davranışlar ve şiddetle ilişkisi. Anadolu Psikiyatri Dergisi, 5, 5-10.

Komarraju M, Karau SJ, Schmeck RR. (2009). Role of the big five personality traits in predicting college students' academic motivation and achievement. Learning and Individual Differences, 19(1), 47-52.

Köse D, Çınar N, Akduran F. (2012). Hemşirelik öğrencilerinde internet bağımlılığının kişilik özellikleri ve zaman yönetimi ile ilişkisi. Sakarya Üniversitesi Fen Bilimleri Enstitüsü Dergisi, 16(3), 227-233.

Lourinho I, Moreira A, Mota-Cardoso R, Severo M, Ferreira MA. (2016). Associations between the big five personality traits and a medical school admission interview. Acta Médica Portuguesa, 29(12), 796-802.

McDermott R, Hatemi PK. (2017). The relationship between physical aggression, foreign policy and moral choices: Phenotypic and genetic findings. Aggressive Behavior, 43(1), 37-46.

Özcan NK, Bilgin H. Türkiye'de sağlık çalışanlarına yönelik şiddet: Sistematik derleme. Türkiye Klinikleri J Med Sci 2011;31(6):1442-56. 
Oxford dictionary online. (2018). Meaning of personality.Accessed date: 29.10.2020, https://en.oxforddictionaries.com/definition/personali ty

Oxford dictionary online. (2018). Meaning of violence. Accessed date: 29.10.2020, https://en.oxforddictionaries.com/definition/violence

Özpulat F. (2017). Hemşirelik öğrencilerinin şiddet eğilimleri ile toplumsal cinsiyet algıları arasındaki ilişki. Başkent Üniversitesi Sağlık Bilimleri Fakültesi Dergisi, 2(2), 151-161.

Özsoy E, Yıldız G. (2013). Kişilik kavramının örgütler açısından önemi: Bir literatür taraması. İşletme Bilimi Dergisi, 1(2), 1-12.

Öztürk M, Yancı HBA, Türksoy A, Yıldız E. (2014). İstanbul Üniversitesi öğrencilerinin fakültelere göre kişilik özelliklerinin ve sağlıklı yaşam biçimi davranışlarının incelenmesi. Spor Bilimleri Dergisi, 4(1-2), 39-44.

Republic of Turkey Prime Ministry Institution of Family Research. (1998). Aile içinde ve toplumsal alanda şiddet. Ankara: Prime Ministry Printing House. Accessed date: 29.10.2020, https://docplayer.biz.tr/7607513-T-c-basbakanlikaile-arastirma-kurumu-baskanligi-aile-icinde-vetoplumsal-alanda-siddet-ankara.html

Schmitt DP, Allik J, McCrae RR, Benet-Martínez V. (2007). The geographic distribution of Big Five Personality Traits: Patterns and profiles of human self-description across 56 nations. Journal of CrossCultural Psychology, 38(2), 173-212.

Sümer N. (2005). "Beş Faktör Kişilik Özellikleri (Big Five Inventory) Anketi Türkçeleştirme Çalışması" (unpublished work).

Tatlılıoğlu K. (2014). Üniversite öğrencilerinin beş faktör kişilik kuramına göre kişilik özellikleri alt boyutlarının bazı değişkenlere göre değerlendirilmesi. Journal of History School, 7(17), 939-971. http://dx.doi.org/10.14225/Joh400

Tosunöz IKK, Öztunç G, Eskimez Z, Demirci PY. (2019). Hemşirelik öğrencilerinin şiddet eğilimlerinin belirlenmesi. Çukurova Medical Journal, 44(2), 471 478.

Ulloa EC, Hammett JF, O’Neal DN, Lydston EE, Aramburo LFL. (2016). The Big Five Personality Traits and intimate partner violence: findings from a large, nationally representative sample. Violence and Victims, 31(6), 1100-1115.

Ulu M. (2016). Kişilik ve şiddet ilişkisi üzerine psikolojik bir araştırma. Bilimname, 32(3), 57-82.

World Health Organization (WHO) (2014). Global status report on violence prevention, WHO Library Cataloguing-in-Publication Data World report on violence and health. Accessed date: 29.10.2020, http://www.who.int/violenceprevention/approach/ definition/en/
Yıldız E, Erci B. (2011). Anne baba tutumları ile adölesan saldırganlığı arasındaki ilişkinin incelenmesi. Düzce Üniversitesi Sağlık Bilimleri Enstitüsü Dergisi, 1(3), 6-11.

Yöyen EG. (2017). Şiddet türleri ve kişilik özellikleri. Yaşam Becerileri Psikoloji Dergisi, 1(1), 35-50.

Yüksel A, Engin E, Öztürk TE. (2015). Hemşirelik öğrencilerinin şiddet eğilimlerinin incelenmesi. Uluslararası Sosyal Araştırmalar Dergisi, 8(41), 834840.

Ziapour A, Kianipour N. (2015). A study of the relationship between characteristic traits and employee engagement (A case study of nurses across Kermanshah, Iran in 2015). Journal of Medicine and Life, 8(Spec Iss 3), 134-140. 